УДК 331.108.4

Бегун C.I.

кандидат економічних наук, доцент,

доцент кафедри обліку та аудиту

Східноєвропейського національного університету імені Лесі Українки

https://orcid.org/0000-0003-1689-4048

Придатко Ю.М.

студент факультету економіки та управління

Східноєвропейського національного університету імені Лесі Українки

Begun S.I.

$\mathrm{PhD}$ in Economics, Associate Professor,

Associate Professor of Accounting and Audit

Lesya Ukrainka Eastern European National University

https://orcid.org/0000-0003-1689-4048

Prydatko J.M.

student of the Faculty of Economics and Management

Lesya Ukrainka Eastern European National University

\title{
ОСОБЛИВОСТІ ФОРМУВАННЯ СУЧАСНИХ ЕКОНОМЕТРИЧНИХ МОДЕЛЕЙ В СИСТЕМІ МЕНЕДЖМЕНТУ ПІДПРИЕМСТВА
}

\author{
Східноєвропейський національний університет імені Лесі Українки
}

\begin{abstract}
Специфіка функціонування провідних економічних систем світу та транснаціональних корпорацій зокрема, свідчить про необхідність широкого застосування специфічного економіко-математичного інструментарію для вирішення проблем планування економічного розвитку, розширення виробництва та побудови багатофункціональних та складних логістичних систем в умовах глобальної економіки та посилення інтернаціоналізації світових сировинних, товарних, фінансових, фондових та валютних ринків. Особливість застосування подібних економетричних моделей полягає в необхідності забезпечення їх якомога більшої точності з одного боку, а з іншого - потребує врахування багатьох різноманітних ринкових індикаторів, які впливають на діяльність провідних економік та окремих крупних компаній світу. Відповідно, менеджмент сучасних компаній неможливий без реалізації багатофакторних моделей економічного прогнозування.

У статті розглянуто сучасні особливості розвитку інформаційних моделей економічного планування та прогнозування в системі менеджменту. На основі аналізу економіко-математичних методів визначено, що їх застосування в процесі прийняття рішень на сучасному етапі економічного розвитку сприяє підвищенню ефективності функціонування підприємств. Розглянуто специфіку застосування визначених економетричних методів та моделей в різних умовах для прогнозування та планування діяльності суб’єктів господарювання. Визначено комплекс факторів, які можуть призводити до зміни суттєвих параметрів економетричних моделей. Запропоновано комплекс заходів по уникненню зазначених ризиків і оптимізації застосування економіко-математичних моделей.
\end{abstract}

Ключові слова: економетрика, кореляційний аналіз, економічне моделювання, економікоматематичне прогнозування

\section{FEATURES OF FORMATION OF MODERN ECONOMETRIC MODELS IN THE ENTERPRISE MANAGEMENT SYSTEM}

\section{Lesya Ukrainka Eastern European National University}

The specifics of the world's leading economic systems and transnational corporations in particular, indicates the need for widespread use of specific economic and mathematical tools to address economic development planning, expand production and build multifunctional and complex logistics systems in the global economy and strengthen internationalization of world raw materials, commodities, financial, stock and currency markets. The peculiarity of the application of such econometric models is the need to ensure their maximum accuracy on the one hand, and on the other - requires consideration of many different market indicators that affect the activities of leading economies and individual major companies in the world. Accordingly, the management of modern companies is impossible without the implementation of multifactor models of economic forecasting. 
The article considers the modern features of the development of information models of economic planning and forecasting in the management system. Based on the analysis of economic and mathematical methods, it is determined that their application in the decision-making process at the present stage of economic development helps to increase the efficiency of enterprises. The specifics of application of certain econometric methods and models in different conditions for forecasting and planning the activities of economic entities are considered. A set of factors that can lead to changes in significant parameters of econometric models is identified. A set of measures to avoid these risks and optimize the use of economic and mathematical models is proposed. forecasting

Keywords: econometrics, correlation analysis, economic modeling, economic and mathematical

Постановка проблеми у загальному вигляді та ії зв'язок з важливими науковими та практичними завданнями. Особливості сучасної глобальної економічної системи унеможливлює відособлене функціонування окремих національних ринків. Процес взаємного проникнення економічних систем внаслідок міжнародної інтеграції ставить нові завдання перед менеджментом підприємств усіх форм власності. I ці завдання передбачають широке застосування специфічних методів та моделей в процесі планування та прогнозування діяльності підприємств для оцінки потенційних ризиків та врахування максимально можливого числа ринкових факторів, котрі супроводжують їх діяльність. Особливої актуальності такі процеси набувають в процесі залучення до глобальної конкуренції все більшого числа підприємств, які раніше обмежувалися виключно діяльністю на національних ринках. Втім, проникнення транснаціональних мереж в національні економіки змушує і невеликі фірми та компанії конкурувати з глобальними корпораціями на своїх, іноді навіть - регіональних ринках.

В таких умовах особливої актуальності набуває проблема формування конкурентних переваг за рахунок використання внутрішніх резервів підприємств щодо покращення якості продукції та зниження виробничих витрат. Адже конкуренція 3 крупними мережами на фінансових ринках для окремих підприємств $є$ задачею нездійсненною.

Відтак, одним із наявних резервів зниження витрат підприємств в подібних умовах $є$ оптимізація та зниження витрат за рахунок більш чіткого, виваженого та економного використання наявних ресурсів. Досягти цієї мети дозволяє застосування специфічних економіко-математичних та економетричних методів планування та прогнозування діяльності підприємств. Використання подібного аналітичного інструментарію дозволяє навіть невеликими компаніям значно знизити витрати виробництва i формувати високоточні плани стосовно залучення та найбільш оптимального використання виробничих та фінансових ресурсів. Таким чином можна стверджувати, що на даному етапі економічного розвитку питання широкого впровадження застосування в діяльності підприємств сучасних економіко-математичних методів та моделей набуває особливої актуальності і потребує поглибленого дослідження в усіх його аспектах.

Аналіз останніх досліджень і публікацій, у яких започатковано вирішення даної проблеми. Дослідженням проблем забезпечення ефективного впровадження в діяльність підприємств економетричних методів та моделей, а також широкого використання їх менеджментом підприємств займалося широке коло вітчизняних дослідників, таких як О. В. Козьменко [2], О. Є. Лугінін [3], О. М. Назаренко [4], С. I. Наконечний та Т. О. Терещенко [5]. Крім того, варто зауважити на значний вклад досліджень особливостей економіко-математичного моделювання у виробничих системах, викладених в працях таких зарубіжних дослідників, як Д. Ендрюс [8], X. Койценкампф та Дж. Магнус [9], Дж. К. МакКі-Мейсон [10] та інших. Втім, проблематика, яка постає перед підприємствами внаслідок глобалізації та інтенсивного впровадження новітніх технологій потребує більш детального вивчення специфічних аспектів запровадження та використання економетричних моделей в процес економікоматематичного планування виробничої діяльності окремих компаній. 
Цілі статті. Метою роботи є дослідження сучасних особливостей формування та впровадження в діяльність комерційних підприємств сучасних економіко-математичних методів та моделей, а також визначення впливу наявного економетричного інструментарію на загальну ефективність функціонування системи менеджменту цих підприємств за рахунок об'єктивної мінімізації та оптимізації загальновиробничих витрат, а також використання зазначених моделей в процесі стратегічного планування та прогнозування розвитку підприємств та формування їх ефективної ринкової стратегії за існуючих умов та ресурсних обмежень.

Викладення основного матеріалу дослідження 3 повним обгрунтуванням отриманих наукових результатів.

Застосування економетричних моделей в системі прийняття рішень менеджментом підприємства стосовно вирішення стратегічних або поточних питань функціонування суб'єкта господарювання чи планування його діяльності в майбутніх періодах передбачає, перш за все, ознайомлення персоналу, аналітиків компаній, а також менеджерів, котрі відповідальні за прийняття рішень щодо впровадження одержаних за рахунок застосування економіко-математичних моделей результатів у практику діяльності компанії, із самою специфікою економетричних моделей, їх можливостей та факторів, котрі впливають на прийняття рішень. Виходячи з цього, виникає необхідність адаптації наявного економетричного інструментарію до вимог та потреб менеджерів підприємств, відповідальних за прийняття рішень щодо прогнозування значень ендогенних змінних або регресантів. Проте, як показує практика, сам процес дослідження зв'язків між критеріальними показниками та факторами, які на них впливають може бути ефективно реалізований лише за умови використання адекватних моделей економетричного аналізу. Відтак, існує потреба виділення комплексу моделей, які можуть реально забезпечити потребу підприємств в якісному прогнозування економічних процесів на основі фактичних даних (рис. 1).

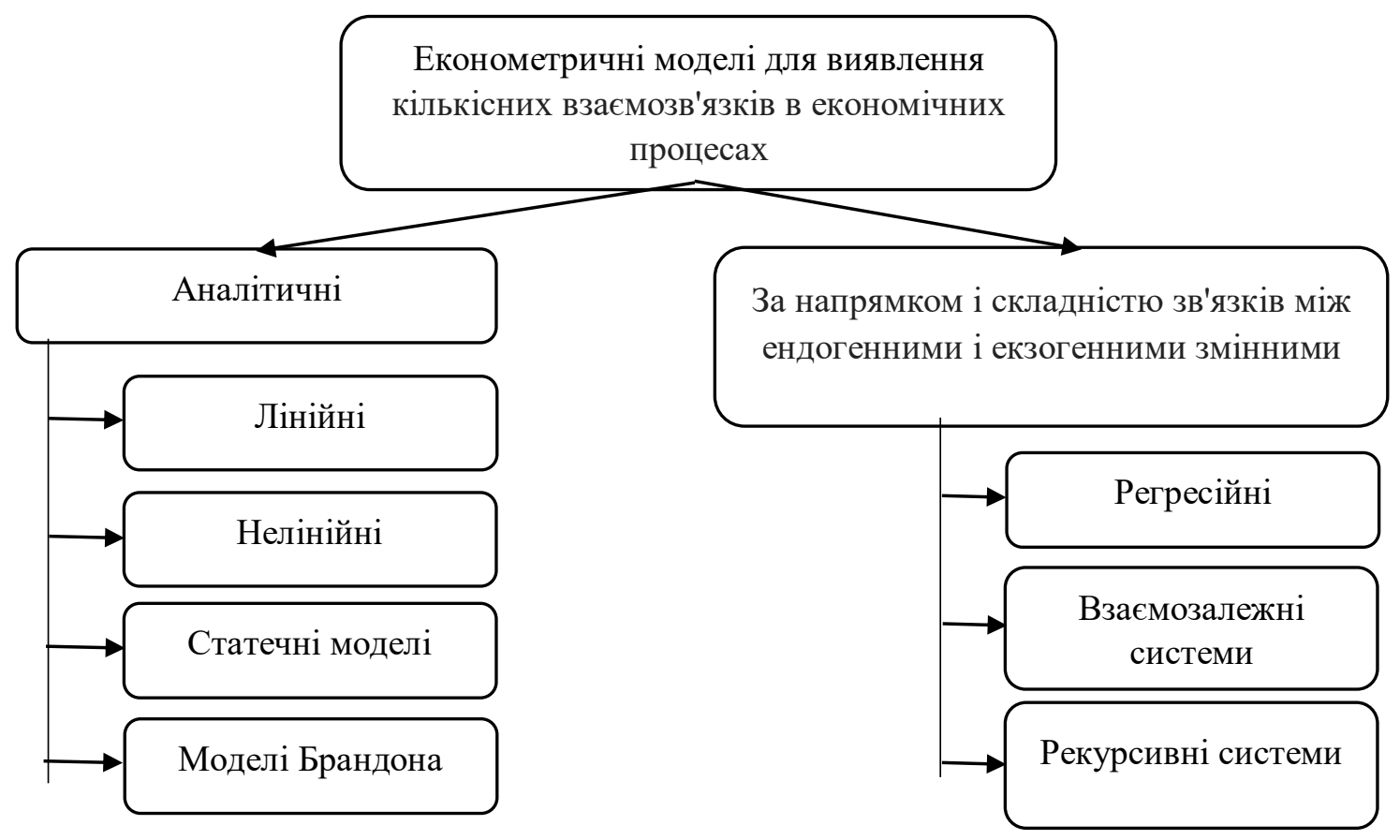

Рис. 1. Схема класифікації економетричних моделей, які використовуються для виявлення кількісних взаємозв'язків в економічних процесах

Джерело: згруповано авторами. 
При цьому практичне використання тієї чи іншої моделі для використання менеджментом підприємства залежить уже від його конкретних потреб в аналітичних даних та галузевої специфіки самого суб'єкта господарювання, а також від доступності та достатності вихідних даних аналізу.

Використання інших підходів до формування економіко-математичних моделей діяльності підприємства також $є$ доцільним за умови їх відповідності потребам управлінської ланки компанії. Так, В. Дорофєєва пропонує використовувати в даному аспекті факторну методику оцінки впливу зовнішнього середовища на підприємства за допомогою методу експертних оцінок. При цьому ступінь впливу в даній методиці виражається через інтегральний показник з врахуванням таких складових, як: параметри ринку, оцінювання впливу соціально-економічних чинників, оцінювання конкуренції всередині галузі, вплив сили постачальників та споживачів [1, с. 36].

Якщо ж вести мову про конкретні методи економетричного аналізу, які дозволяють практично реалізувати і адаптувати вищезазначені моделі до конкретних потреб підприємства, то необхідно зауважити, що на в системі економіко-математичного інструментарію виділяють кілька вагомих та достовірних методів, за допомогою яких вирішуються питання економіко-математичного моделювання. До таких методів, перш за все, відноситься кореляційно-регресійний аналіз, який, до того ж, є найбільш часто застосовується в практиці менеджменту. При цьому правильне застосування методів кореляційного аналізу дає змогу визначити причини та особливості побудови загального процесу економічних взаємозв'язків в аналізованій системі.

Як зазначає Ю. Скляров, використання методу кореляційно-регресійного аналізу дає змогу вирішити такі основні завдання:

1) встановити характер і тісноту зв'язку між досліджуваними явищами;

2) визначити і кількісно виміряти ступінь впливу окремих факторів і їх комплексу на рівень досліджуваного явища;

3) на підставі фактичних даних моделі залежності економічних показників від різних факторів розраховувати кількісні зміни аналізованого явища під час прогнозування показників і створити основу для об'єктивного прийняття ефективних рішень щодо управління підприємством [7, с. 107].

Оскільки кореляційно-регресійний аналіз дає можливість проводити складні обрахунки щодо прогнозування багатофакторних економічних процесів, то він виділяється, як ключовий елемент побудови економетричних моделей. Як приклад, можна навести використання кореляційного аналізу для оцінювання міжнародної сукупної продуктивності факторів виробництва (рис. 2).

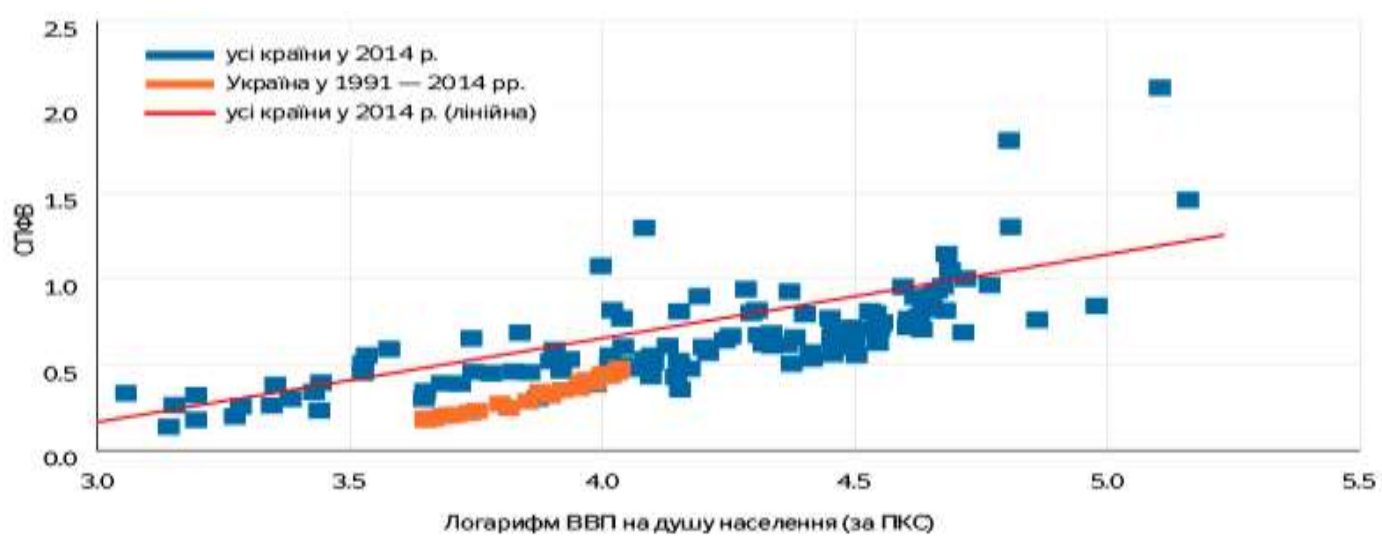

Рис. 2. Приклад використання кореляційного аналізу для оцінювання міжнародної сукупної продуктивності факторів виробництва за 1991 - 2014 роки

Джерело: [6]. 
Як бачимо, при наявності функціональних взаємозв'язків зміна однієї ознаки або факторного показника як наслідок неодмінно викликатиме за собою зміни іншого факторного показника на конкретне, визначене аналізом, значення. Відповідно, економетричні моделі дають можливість менеджменту підприємства за допомогою визначення кореляційних залежностей вагомих факторів економічної системи визначати варіативні значення факторних змінних величин, які використовуватимуться як при плануванні, так і при прогнозуванні діяльності підприємства.

Висновки. Отже, можна зробити висновок, що в сучасних умовах економічної діяльності та інтенсифікованого розвитку і глобалізації світового ринку наявність адекватного потребам суб'єктів господарювання економіко-математичного інструментарію побудови економетричних моделей $є$ визначальним для досягнення цілей ефективної економічної діяльності підприємств. Зокрема, відсутність можливості проведення адекватного аналізу, в свою чергу, унеможливить прогнозування діяльності підприємства та формування стратегічних планів його розвитку, що матиме наслідком неможливість прийняття ефективних управлінських рішень менеджментом такої компанії. Відтак, можна стверджувати, що лише ефективне застосування економікоматематичних та економетричних методів та моделей забезпечить можливості по прийняттю дієвих управлінських рішень, які дозволять ефективно вирішувати проблеми формування средньо- та довгострокових планів розвитку підприємств усіх форм власності.

\section{Список бібліографічного опису}

1. Дорофеева В В. Методика факторной оценки влияния внешней среды на деятельность предприятий. Дискуссия : политематический журнал научных публикаиий. Экономические науки. 2013. Вып. 5-6. С. 35-38. (рос мовою).

2. Козьменко О. В., Кузьменко О. В. Економіко-математичні методи та моделі (економетрика) : навчальний посібник. Суми : Університетська книга. 2014. 406 с.

3. Лугінін О. Є. Економетрія. Навч. пос. 2-е видання, перероб. та доп. Київ : Центр учбової літератури, 2008. 278 с.

4. Назаренко О. М. Основи економетрики: Вид. 2-ге, перероб.: Підручник. Київ : «Центр навчальної літератури». 392 c.

5. Наконечний С. І., Терещенко Т. О., Романюк Т. П. Економетрія: Підручник. Вид. 2-ге, допов. та перероб. Київ : КНЕУ, 2000. $296 \mathrm{c}$.

6. Самаєва Ю. Швидше, вище, сильніше. Дзеркало тижня. 2019. Вип. №5. URL: https://dt.ua/macrolevel/shvidshevische-silnishe-302180_.html

7. Скляров Ю.С. Введение в эконометрику. Санкт-Петербург : ГУАП. 2007. 140 с. (рос. мовою).

8. Andrews D. Tests for parameter stability and structural change with unknown change point. Econometrica. 1993. Vol. 59. P. 817-858.

9. Keuzenkamp H. A., Magnus J. R. On tests and significance in econometrics. Journal of Econometrics. 1995. Vol. 67. P. 524.

10. MacKie-Mason J. K. Econometric software: A user's view. Journal of Economic Perspectives. 1992. Vol. 6, n. 4. P. 165187.

\section{Reference}

1.Dorofeeva V. V Metodika faktornoj otsenki vliyania vneshnej sredy na deyatelnost predpriatii [Methods of factor assessment of the impact of the external environment on the activities of enterprises]. Discussion: a polythematic journal of scientific publications. Economic sciences. 2013. Issue. 5-6. P. 35-38. [in Russian].

2.Kozmenko O. V., Kuzmenko O. V. Ekonomiko-matematychni metody ta modeli (ekonometria) [Economic and mathematical methods and models (econometrics)]. Sumy : University book. 2014. 406 p. [in Ukrainian].

3.Luginin O. E. Ekonometria [Econometrics]. Kyiv : Center for Educational Literature, 2008. 278 p. [in Ukrainian].

4. Nazarenko O. M. Osnovy ekonometryky [Fundamentals of econometrics]. Kyiv : Center for Educational Literature. 392 p. [in Ukrainian].

5.Nakonechnyi S. I., Tereshchenko T. O., Romaniuk T. P. Ekonometria [Econometrics]. Kyiv : KNEU, 2000.296 p. [in Ukrainian].

6.Samaeva Yu. Shyydshe, vyshche, sylnishe [Faster, higher, stronger]. Mirror of the week. 2019. Vol. №5. URL: https://dt.ua/macrolevel/shvidshe-vische-silnishe-302180_.html. [in Ukrainian].

7.Skliarov Yu. S. Vvedenie v ekonometrike. [Introduction to econometrics]. St. Petersburg : GUAP. 2007. 140 p. [in Russian]. 8. Andrews D. Tests for parameter stability and structural change with unknown change point. Econometrica. 1993. Vol. 59. P. 817-858.

9. Keuzenkamp H. A., Magnus J. R. On tests and significance in econometrics. Journal of Econometrics. 1995. Vol. 67. P. 524.

10. MacKie-Mason J. K. Econometric software: A user's view. Journal of Economic Perspectives. 1992. Vol. 6, n. 4. P. 165187.

Дата подачі публікації 03.06.2020 